DOI: $10.2478 /$ lpts-2018-0036

APPLIED PHYSICS

\title{
THE INFLUENCE OF ICE TEXTURE ON SLIDING OVER ICE
}

\author{
E. Jansons ${ }^{1,2^{*}}$, K.A. Gross ${ }^{1}$, J. Lungevics ${ }^{1,2}$, \\ L. Pluduma ${ }^{1}$ \\ ${ }^{1}$ Biomaterials Research Laboratory \\ Riga Technical University \\ 3 Paula Valdena Str., Riga, LV-1048, LATVIA \\ ${ }^{2}$ Institute of Mechanical Engineering \\ Riga Technical University \\ 36a Viskalu Str., Riga, LV-1006, LATVIA \\ *e-mail: Ernests.Jansons_1@rtu.lv; kgross@rtu.lv
}

\begin{abstract}
Winter brings snow and ice to Northern Europe and with it the need to move safely over ice. It has been customary to select an appropriate material surface for movement over ice, but another way to influence the interaction with ice is to appropriately prepare the ice surface. The objective of the research is to investigate the influence of ice texture on initiating movement over ice and on sliding velocity over ice in the laboratory and field conditions. The ice has been prepared smooth, scratched and glazed similar to the one found in real life situations. The static coefficient of friction and the sliding speed have been measured at the laboratory, but the sliding speed quantified on a skeletonat the skeleton push-start facility. The scratched ice surface has increased the resistance to movement, thus resulting in the lowest sliding speed under laboratory conditions. Sliding is better on the smooth ice and glazed ice. The contact surfaces have been measured to determine the effect of contact area on sliding properties. Field experiments with heavier loads have flattened the ice surface irregularities for more constant sliding conditions over time. This outcome provides a useful indicator for pedestrians and road traffic related to the safety of movement over different ice surfaces as well as a reference for those involved in winter sports.
\end{abstract}

Keywords: contact area, ice friction, inclined plane, ice texture, sliding velocity, tribology 


\section{INTRODUCTION}

Ice surface in real life situations forms in different ways because freezing is strongly affected by weather conditions and other external influences from society. In nature, different ice surfaces can be observed around us. For example, if the precipitation under changing weather conditions turns from snow to rain, it is likely that raindrops freeze and form spherical droplets on the surface, thus making a wavy texture. Another situation can be observed if the air temperature drops after wet weather conditions and the ice surface of the puddle or other standing water is smooth. In the field of winter sports, the ice surface can be even more important to achieve the best results especially if athletes use the track one after another; the ice conditions between the first and the last participant could be significantly different. Despite the active research on the interaction between ice and the sliding object, there is little or no mention of the ice texture. The knowledge of how ice texture affects the sliding speed can be valuable in the sports industry, transportation sector and provide new insights for those involved in research. This study will emphasise the importance of ice texture in ice tribology.

The interaction between ice and solid object is one of the most complicated tribological systems due to many influencing factors such as contact pressure, surface roughness, hydrophobicity, macro geometry of the object, ice and ambient temperature, relative humidity, liquid like layer (LLL) thickness, etc. Nevertheless, usually ice surface texture is not characterised enough believing that effect on the results is not significant. The lack of an easy-to-use methodology for characterisation of the ice surface is another reason for poorly described texture of ice in many previous studies.

The ice contact area can be determined by making a replica of the ice surface. Using this method, Baurle et al. [1] measured 2D ice roughness and observed a 4-fold difference in the average roughness $\mathrm{Pa}$ (arithmetical mean height for primary profile) between undisturbed ice $(0.07 \mu \mathrm{m})$ and ice on the ice track $(0.3 \mu \mathrm{m})$. A similar approach with ice replicas by Spagni et al. [2] reported an average roughness parameter $\mathrm{Ra}$ (arithmetical mean height for roughness profile) of $0.1 \mu \mathrm{m} \pm 0.01$.

Two dimension roughness measurements provide an insight, but a $3 \mathrm{D}$ measurement is required for more detail. Ducret et al. [3] previously used textured moulds to produce different ice surface textures in order to measure the effect of ice roughness on the coefficient of friction (COF). The surface texture of moulds was measured in 3D (across the entire surface). Using an angle between a sliding object and ice asperities surface smoothness was determined. The COF measurements from two different ice surfaces showed a 4-fold increase in COF by changing ice texture from a smooth surface to a more glazed ice.

Contact area between ice and sliding object is one of the main factors influencing the movement over ice. Measuring sliding friction of polyethylene over ice, Baurle et al. [1], [4] concluded that the main factors influencing friction over ice were a real contact area and a liquid-like layer. It was observed that the coefficient of friction increases as a contact area increases. Rohm et al. [5] investigated the influence of metal ski surface roughness on the coefficient of friction. It was concluded that smoother surfaces with a larger contact area had a higher COF than rough surfaces. As a result, adhesion force increased which resulted in higher COF between 
metal ski and suppressed snow. A higher COF was observed at warmer temperatures, when the liquid-like layer was thicker and the adhesion force was higher. The effect of the contact area was lower at lower temperatures and faster velocities. Using calculations, Scherge et al. [6] stated that a higher contact area could lead to increased velocity due to a thicker film of the melt water.

To investigate the significance of the ice surface texture on the tribological properties between ice and the moving object, three fundamentally different ice surfaces have been created to determine the static coefficient of friction and sliding speed. In order to perform such experiments, two devices based on the inclined plane principle have been used at the laboratory. Both of these devices have previously been tested and proven to be reliable and useful for such tests [7]. Results are analysed taking into account the contact area between ice and sliding object; the contact area has been measured with a simple test method that shows the top surface. The goal of the study is to demonstrate how object sliding speed and the coefficient of friction are affected by different ice textures.

\section{MATERIALS AND METHODS}

\subsection{Experimental Setup}

\section{Laboratory Setup}

Laboratory experiments have been conducted under controlled ambient conditions in a cold room $(\mathrm{W} / \mathrm{L}=3.5 \mathrm{~m}, \mathrm{H}=2.2 \mathrm{~m})$. Two inclined plane principle based devices have been used to study tribological properties between ice and stainless steel:

a. Sliding speed of the laboratory samples has been measured on a $3.3 \mathrm{~m}$ long ice track. The track angle has been set to $16^{\circ}$ and remained constant throughout all experiments. This plane angle has been chosen to ensure sliding a stationary position, and provide a long enough sliding time to detect differences on various ice textures. Sliding speed has been measured using four retroreflective sensors arranged along the length of the track [7].

b. The static coefficient of friction has been measured using a shorter inclined plane as shown in Fig. 1. The angle $\alpha$ of the initially horizontal ice track is slowly increased until the sample overcomes static friction and initiates sliding down the plane. To initiate sliding, the plane angle is noted at an accuracy of $30^{\circ}$. The static coefficient of friction (COF) has been calculated as tangent of the measured angle.

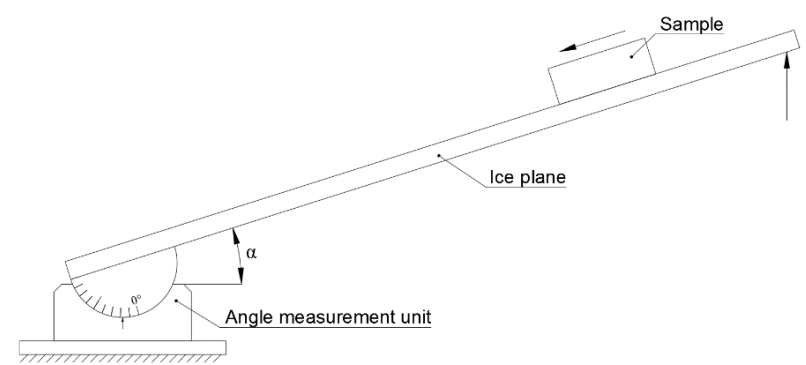

Fig. 1. Principal scheme of the static coefficient of friction. 
Experimental samples have been made from an International Bobsleigh and Skeleton Federation (IBSF) standardised austenite structure stainless steel $(62 \% \mathrm{Fe}$; $15.8 \% \mathrm{Ni} ; 13.8 \% \mathrm{Cr} ; 5 \% \mathrm{Mo} ; 1.4 \% \mathrm{Co} ; 1.2 \% \mathrm{Mn} ; 0.8 \% \mathrm{Cu}$ ) as rectangular blocks with dimensions of $35 \times 18 \times 14 \pm 0.2 \mathrm{~mm}$ and weight of $67 \pm 0.5 \mathrm{~g}$. The material has been chosen because of its good anti-corrosion properties.

Samples have been milled from one workpiece and the sliding surface made smooth by grinding and polishing on an automated polisher - Mecatech 334 TI 15 (Presi, FRA) to an average surface roughness, Sa, $10 \mathrm{~nm}$. Before experiments, samples have been placed in the cold room to cool down for at least 10 minutes. Gloves with low thermal conductivity have been used while working with samples to prevent sample heating.

\section{Field Experiment}

A 24-m long ice-track located in Sigulda bobsleigh track push-start training facility has been used for field tests. The experiment setup has not provided full control of the ambient conditions, but the ice surface has still been protected from the influence of wind, snow and sun [8].

The track has been equipped with two optical sensor pairs (four sensors in total), which has allowed measuring the sliding speed of the skeleton sled while its moving down an angled plane. The ice track has been protected from wind, snow and sun, but a grill on the floor enabled air circulation for the temperature and relative humidity to equilibrate with the outside conditions. A U-shaped groove $(20 \mathrm{~mm}$ diameter) has been formed in the ice track in order to guide the skeleton along the same path for every run.

The skeleton sled has been used as an experimental sample due to its relatively simple construction and relatively large runner contact area with ice. Runners that were $1000 \mathrm{~mm}$ long and $16 \mathrm{~mm}$ wide freely sat in the U-shaped ice groove. The runners are made of the same austenite structure steel as laboratory samples and polished manually using 3000 grade sand paper, to a surface roughness Sa of $\sim 0.14$ $\mu \mathrm{m}$. Metallic debris and sandpaper particles after polishing have been removed with a tissue soaked in ethanol. After cleaning, the sled has been placed on the ice surface for at least 10 minutes to even runner and ice temperature.

\subsection{Preparation of Ice and Contact Area Measurements}

On laboratory track, boiled tap water $\left(\sim 70^{\circ} \mathrm{C}\right)$ has been poured into the horizontally levelled U-shaped channel, layer by layer, to ensure homogenous ice without cracks and air inclusions. Every next layer has been added after previous one has been frozen. A total of 5 layers have been collected to fill the entire channel volume. When the ice has been frozen, a small groove has been placed in the ice surface with a planer. The groove has ensured that the steel blocks have followed the same path. The planer has also made a flat base before making changes to the ice texture.

Similarly as in laboratory, the base of the 24-m long ice track has been formed 
layer by layer using hot water to fill pores and cracks in the previous layer only this time the number of layers is significantly larger. Once the desired thickness is achieved, the ice surface is planned and a straight groove with a diameter of $20 \mathrm{~mm}$ is made in the ice in order to guide one runner of the skeleton.

Ice has been made to three different ice textures - smooth, scratched and glazed. To prepare a smooth surface (Fig. 2. a), a thin layer of boiled water $\left(\sim 70^{\circ}\right.$ C) has been poured into previously planned inclined plane groove and then frozen for 10 to 20 minutes, based on the chosen air temperature. In order to prepare scratched surfaces (Fig. 2.b), a 60 grade sandpaper (Klingspor) has been used to prepare scratches parallel and perpendicular to the motion of the sliding body. After ice is scratched, particles from sandpaper and ice debris are carefully removed using a brush. For surface with solidified ice droplets (glazed ice), an atomiser has been used to simulate small rain droplets (Fig. 2.c). Cold water $\left(\sim 2^{\circ} \mathrm{C}\right)$ has been sprayed $\sim 20$ $\mathrm{cm}$ from the ice surface. Water temperature has been kept at $2^{\circ} \mathrm{C}$ in order to minimise the temperature difference between the droplet and the ice surface.

a)

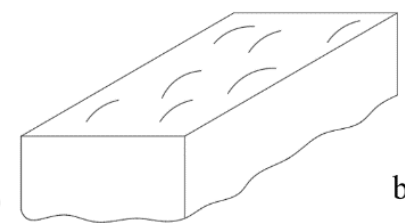

b)

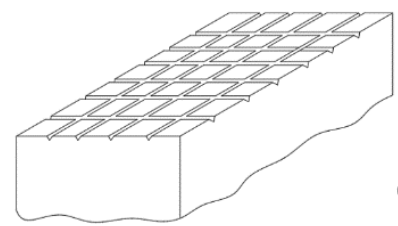

c)

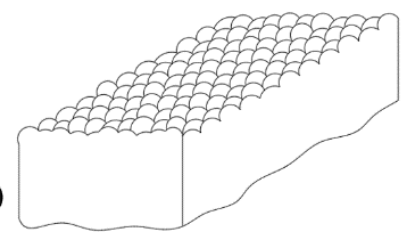

Fig. 2. Ice surfaces: a) Smooth; b) Scratched; c) Glazed.

All ice textures have been imaged using a 1000 x USB Digital Microscope (Gaosuo, CHN) from both the laboratory and the push-start facility. This type of microscope has been chosen because it can be easily transported and could be used in cold conditions.

In order to estimate the ice contact area, a method has been used to highlight the top surface. Water-based black ink has been poured on the modified ice surface that drained to the lower areas of all the modified surfaces. Microscope images have been processed with Photoshop (Adobe, USA) software to determine the percentage of "black" and lighter areas of each image. The lighter areas representing the higher points on ice have been presumed to be the contact surface with a sliding object. This simple, fast and practical method for measuring the top surface has provided an alternative to contact surface measurements from ice-replicas and profilometry experiments.

\subsection{Experimental Settings}

Three different experiments have been conducted to determine sliding of stainless steel on various ice textures: a) sliding speed at the laboratory, b) the static coefficient of friction at the laboratory, c) sliding speed of the skeleton at the pushstart facility. Experimental conditions are summarised in Table 1. 
Experimental Settings

\begin{tabular}{|c|c|c|c|}
\hline \multirow{2}{*}{ Settings } & \multicolumn{2}{|c|}{ Laboratory experiments } & \multirow{2}{*}{$\begin{array}{c}\text { Field experiments } \\
\text { Sliding velocity }\end{array}$} \\
\hline & Sliding velocity & Static coefficient of friction & \\
\hline $\begin{array}{l}\text { Air temperature }\left({ }^{\circ}\right) \text {; } \\
\text { (Relative humidity) }\end{array}$ & $-6.0 ;(70 \%)$ & $-6.0 ;(70 \%)$ & $\begin{array}{l}\text { Day 1: }-1.0 ;(85 \%) \\
\text { Day 2: }-4.0 ;(72 \%) \\
\text { Day 3: }-4.0 ;(75 \%) \\
\text { Day 4: }-9.0 ;(70 \%)\end{array}$ \\
\hline Ice temperature, $\left({ }^{\circ}\right)$ & -5.0 & -5.0 & $\begin{array}{l}\text { Day 1: }-4.0 \\
\text { Day 2: }-5.0 \\
\text { Day 3: }-5.0 \\
\text { Day 4: }-9.0\end{array}$ \\
\hline Experimental sample & $\begin{array}{c}\text { Rectangular } \\
\text { stainless steel } \\
\text { block }\end{array}$ & $\begin{array}{l}\text { Rectangular stainless steel } \\
\text { block }\end{array}$ & $\begin{array}{l}\text { Skeleton sled with two } \\
\text { stainless steel runners }\end{array}$ \\
\hline Surface roughness, $(\mu \mathrm{m})$ & $0.01 \pm 0.02$ & $0.01 \pm 0.02$ & $0.14 \pm 0.04$ \\
\hline Load & $67 \pm 0.5 \mathrm{~g}$ & $67 \pm 0.5 \mathrm{~g}$ & $95 \pm 0.2 \mathrm{~kg}$ \\
\hline Experimental days & 4 & 4 & 4 \\
\hline Experimental samples & 4 & 4 & 1 sled with 2 runners \\
\hline $\begin{array}{l}\text { Total measurements for } \\
\text { one sample }\end{array}$ & 240 & 120 & 60 \\
\hline
\end{tabular}

* Variation in the air and ice temperature is $\pm 1{ }^{\circ} \mathrm{C}$; in air humidity $\pm 2 \%$

The temperature and humidity at the laboratory have been set to the same conditions to test for repeatability. The field experiments at the push-start facility provide different conditions for all four experimental days. The air temperature and humidity have been measured with a P330 Temp (Dostmann, GER), and ice surface temperature has been measured with a contact thermocouple TP-122-100-MT-K (Czaki, PL) plugged in Proscan 520 (Dostmann, GER) thermometer for both laboratory and field experiments.

A total of four rectangular stainless steel blocks with the same weight, surface texture and dimensions have been used for laboratory experiments. In field experiments, the surface of the skeleton runners has been manually re-polished before each experimental day. The laboratory and field experiments have shown sliding under different contact pressures.

Total number of tests performed for one sample at the laboratory has been 240 for sliding speed experiments and 120 for coefficient of friction experiments. Field experiments involved a total of 60 sliding speed measurements. A large number of the measurements have provided statistically reliable data.

\section{RESULTS AND DISCUSSION}

\subsection{Ice Surface Contact Area}

Images from five randomly chosen locations have been taken for each ice texture (see examples in Fig. 4.) and the average contact area has been calculated. 
Contact area ("grey" colour in Fig. 4.) has been determined as a percentage of the total surface area from the images. The estimated contact area has been $97 \pm 1 \%$ for smooth ice; $81 \pm 1 \%$ for scratched ice and $38 \pm 5 \%$ for glazed ice. The random distribution of ice droplets on glazed ice has resulted in an uneven ice texture and a corresponding large variation $(5 \%)$.

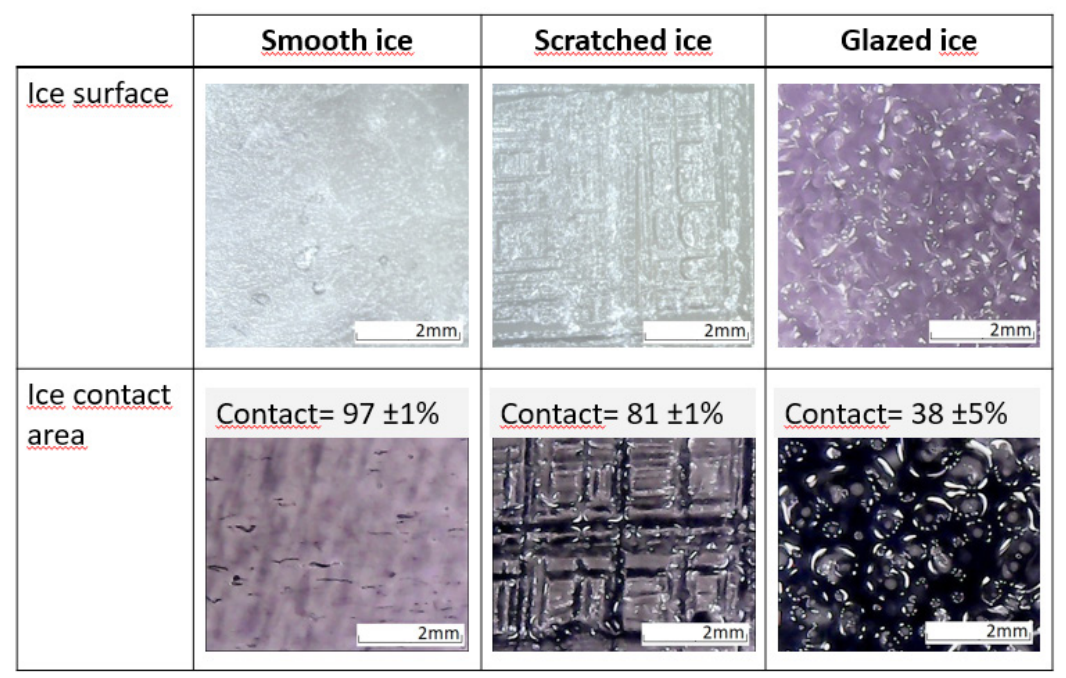

Fig. 4. The ice surface and the contact area of smooth, scratched and glazed ice.

\subsection{Laboratory Experiments}

\section{Static Coefficient of Friction}

Static coefficient of friction (COF) has been calculated as an average of 120 measurements for each ice surface. The smallest COF value $(0.072 \pm 0.018)$ has been observed on the glazed ice (Fig 5a). Approximately 1.6 times larger COF values (0.117) have been observed for smooth and scratched ice with standard deviations of 0.033 and 0.022 , respectively

The error varies depending on the ice texture. Standard deviation that is almost 2 times higher for smooth ice surface measurements can be explained with a large contact area ( $97 \%$ for smooth ice surface) between ice surface and experimental sample; this is believed to create an increase in the number of capillary bridges between the sliding surface and ice [9]. Capillary bridges vary in each experiment, contributing to the scatter in the results. Increasing the thickness of the so-called "liquid-like layer" has been suggested to increase the adhesive force between the sliding object and ice resulting in more variable results. A similar explanation can be given to the small static coefficient of friction on glazed ice; the small contact area reduces adhesion between surfaces, but the similar surface area of smooth and scratched ice is not sufficient to differentiate the results. Similar observations about the scatter of the results were found by Baurle et al. [4] with pin-on-disc tribometer tests where an increase in contact area gave a larger variation of the results. 

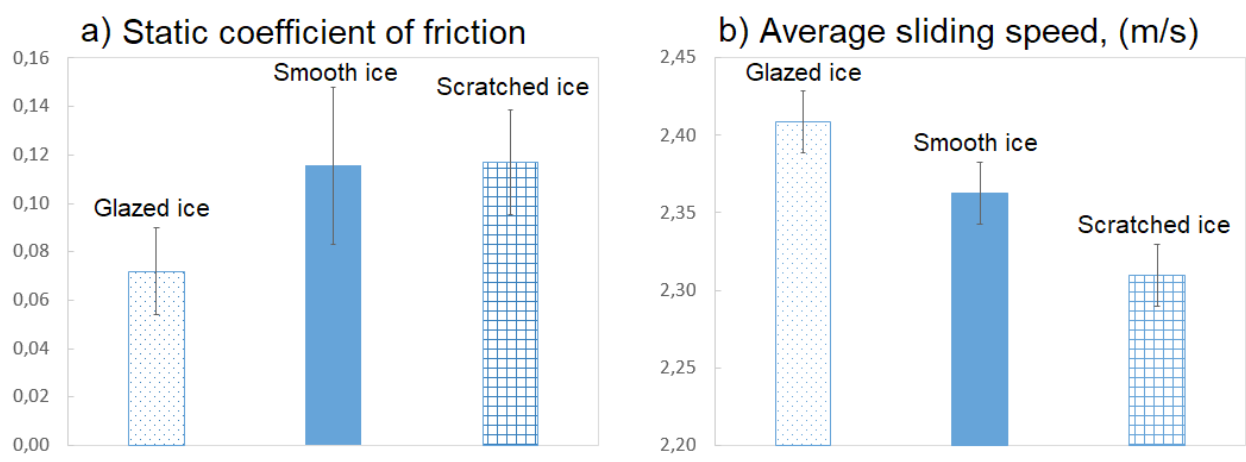

Fig. 5. The co-efficient of friction and the sliding speed for glazed ice, smooth ice and scratched ice show easier sliding on glazed ice.

\section{Sliding Speed}

Faster sliding on ice has presented a lower contact with the sliding object. The average sliding speed for the laboratory samples has been calculated from at least 960 measurements on each type of the ice surface (Fig. 5.b.). Similar tendencies for sliding speed appear on all experimental days. The highest sliding speed has been observed on glazed ice $(2.409 \mathrm{~m} / \mathrm{s})$; on smooth ice, the sliding speed has been reduced by $\sim 2 \%(2.363 \mathrm{~m} / \mathrm{s})$ while the lowest sliding speed $(2.310 \mathrm{~m} / \mathrm{s})$ has been observed on the scratched ice ( $4 \%$ slower).

The experiments have clearly demonstrated that faster sliding occurs on glazed ice. The best tribological results for the glazed ice are most likely achieved due to a small contact area (38\%), which reduces overall adhesion forces between surfaces, and the curved form of the ice droplets, which provide easier movement of the sample. Scratched and smooth ice texture provides almost identical static coefficient of friction, but sliding velocity experiments have shown that smooth surface provides better sliding conditions.

Similar tendencies about the influence of the contact area are available in other studies. A metal ski sliding over snow has shown similar results [5]. In Rohm's experiments, the tribological system is opposite to our work, i.e., snow surface is relatively constant while the used skis have different roughness. It was observed that the smallest coefficient of friction resulted from the roughest skies and the tendencies increased with temperature. Rohm et al. considered that such phenomena occured because smoother surfaces had less available volume for the meltwater to spread causing a larger increase in the contact area compared to rougher surfaces. Increase of the contact area increases adhesion and slows movement over ice. Similar findings have been reported from a large-scale rotation tribometer indicating a larger friction from a larger contact surface area [4]. Repeated traverse over the same ice section in rotation tribometer experiments combine the effect of contact area and a thicker water film (that otherwise occurs in warmer conditions) thereby showing a more accentuated effect from the two separate factors, contact area and warmer conditions. 


\subsection{Field Sliding Experiments}

Field tests have been performed using a skeleton as a sliding body to understand the effect of surface contact area under greater contact pressures. The contact pressure from the skeleton has been sufficient to plastically deform the rougher to a smoother surface (Fig. 6).
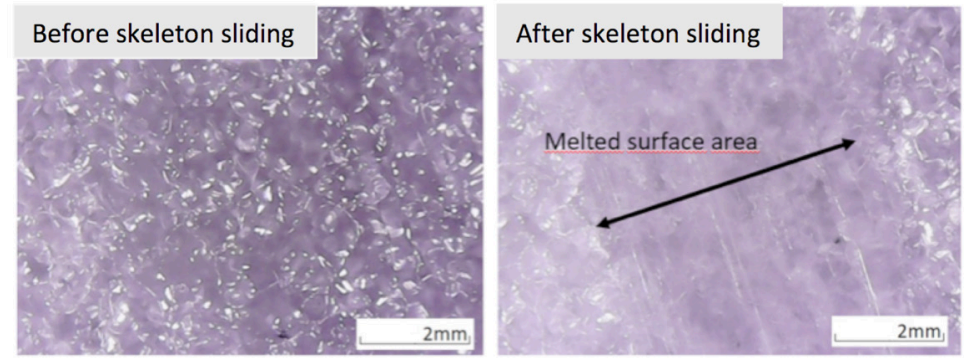

Fig. 6. A glazed ice surface before and after sliding of the skeleton.

Tribological properties of textured ice (glazed and scratched) have changed over time with repeated runs. The sliding speed has changed for the first four runs and then stabilised (Fig. 7).

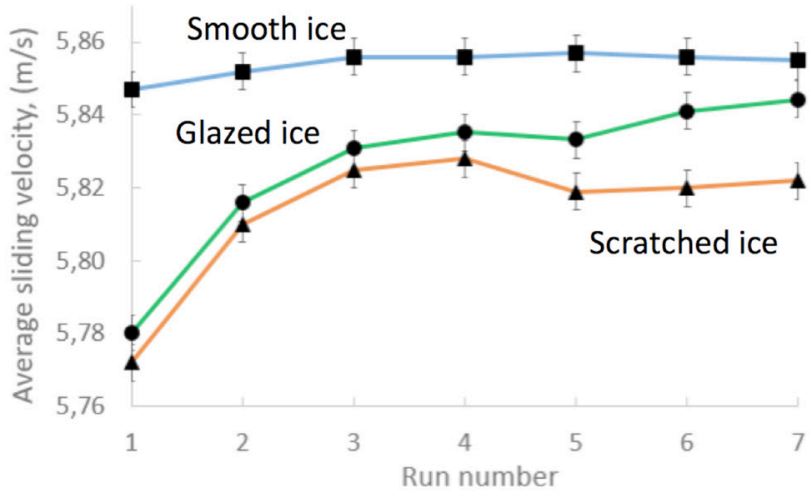

Fig. 7. Sliding velocity ice surfaces. Markers in the graph represent the average sliding velocity of each run calculated from four different experimental days. Dots are used for glazed ice, triangles represent scratched ice and squares represent smooth ice.

The trend of the sliding velocity has remained the same during all experimental days - first run is always the slowest one and sliding velocity increases until it stabilises after $\sim 4$ runs. Frozen droplets and scratches on ice surface interfere with the sled runners; as a result, sled runner melts and squeezes the frozen droplets or builds up edges from scratching, thus smoothening the groove. Rohm et al. studied the metal samples against compressed snow, and also showed that measurement values were changing from one measurement to the next, only the observed tendency was opposite, i.e., during first runs smaller COF value was achieved and after approximately 3 runs the measurement results stabilized. It is interesting to note that this phenomenon is more noticeable on smoother surfaces [5]. 
The observed effect of ice surface modification is opposite for the lighter laboratory samples than for the heavier skeleton in field experiments. If the contact pressure caused by a sliding object is smaller than the yield stress of frozen droplets, improvement of the sliding motion can be observed because the contact area of ice is reduced. But if the pressure of a sliding object is high enough, some of the kinetic energy is dissipated into plastic deformation of the ice surface. Winter sports athletes (skeleton, bobsleigh and luge riders) can therefore expect different results after an increase in the ice contact surface.

The experiments have shown the effect of contact area on sliding speed and emphasised the importance of ice texture. Since the ice contact area is important, further work will evaluate the best method for assessing the contact area, by comparing this method with the use of a replica [4], [2].

Laboratory and field experiments have demonstrated how the contact pressure changes ice tribological properties. Experiments at the laboratory have shown that the glazed ice surface with the smallest static coefficient of friction results in the fastest sliding speed. Further research could address different droplet shapes and the ambient temperature/humidity to study the effect of contact area in more detail.

\section{CONCLUSIONS}

Ice surface texture has a significant impact on sliding speed over ice in both small-scale and large-scale situations. For lighter sliding objects, a smaller contact area apparently reduces the adhesive force between ice for easier sliding. A larger contact area produces a larger coefficient of friction. Large-scale objects deform surface irregularities, leading to changing sliding conditions until a constant speed is reached.

Quick and direct quantification of the ice contact area measures the ice contact surface without the use of specialised devices or ice replicas.

\section{ACKNOWLEDGEMENTS}

The research has been supported by the ERAF project "The Quest for Disclosing how Surface Characteristics Affect Slideability” (No.1.1.1.1/16/A/129). Researchers would also like to acknowledge ice preparation team of Sigulda push-start facility for helping prepare field experiments.

\section{REFERENCES}

1. Baurle, L., Kaempfer, T.U., Szabo, D., \& Spencer, N.D. (2007). Sliding friction of polyethylene on snow and ice: Contact area and modeling. Cold Reg. Sci. Technol., 47, 276 289. doi:10.1016/j.coldregions.2006.10.005

2. Spagni, A., Berardo, A., Marchetto, D., Gualtieri, E., Pugno, N.M., \& Valeri, S. (2016). Friction of rough surfaces on ice: Experiments and modeling. Wear, 368-369, 258-266. doi:10.1016/j.wear.2016.10.001

3. Ducret, S., Zahouani, H., Midol, A., Lanteri, P., \& Mathia, T.G. (2005). Friction and abrasive wear of UHWMPE sliding on ice. Wear, 26-31. doi:10.1016/j.wear.2004.09.0264. 
4. Baurle, L., Szabó, D., Fauve, M., Rhyner, H., \& Spencer, N.D. (2006). Sliding friction of polyethylene on ice: Tribometer measurements. Tribol. Lett., 24, 77-84. doi:10.1007/ s11249-006-9147-z

5. Rohm, S., Hasler, M., Knoflach, C., van Putten, J., Unterberger, S.H., Schindelwig, K. ... Nachbauer, W. (2015). Friction between steel and snow in dependence of the steel roughness. Tribol. Lett., 59, 27. doi:10.1007/s11249-015-0554-x

6. Scherge, M., Böttcher, R., Spagni, A., \& Marchetto, D. (2018). High-speed measurements of steel-ice friction: Experiment vs. calculation. Lubricants, 6, 26. doi:10.3390/ lubricants6010026

7. Lungevics, J., Jansons, E., \& Gross, K.A. (2018). An ice track equipped with optical sensors for determining the influence of experimental conditions on the sliding velocity. Latv. J. Phys. Tech. Sci., 55, 64-75. doi:10.2478/LPTS-2018-0007

8. Jansons, E., Lungevics, J., Stiprais, K., Pluduma, L., \& Gross, K.A. (2018). Measurement of sliding velocity on ice, as a function of temperature, runner load and roughness, in a skeleton push-start facility. Cold Reg. Sci. Technol., 151, 260-266. doi:10.1016/J. COLDREGIONS.2018.03.015

9. Kietzig, A.-M., Hatzikiriakos, S.G., \& Englezos, P. (2009). Ice friction: The effects of surface roughness, structure, and hydrophobicity. J. Appl. Phys., 106, 24303. doi: $10.1063 / 1.3173346$

\title{
LEDUS TEKSTŪRAS IETEKME UZ SLĪDĒ ŠANAS PROCESU PA LEDU
}

\author{
E. Jansons, K.A. Gross, J. Lungevičs, L. Plūduma
}

Kopsavilkums

Ziemeḷu reǵionā dzīvojošajiem cilvēkiem jārēķinās ar ziemu, kas rada apledojumu, pa kuru visi vēlas droši pārvietoties. Līdz šim slīdēšana pa ledu pamatā apskatīta no slīdošā objekta topogrāfijas viedokḷa, bet šo procesu iespējams ietekmēt arī citādi, t.i., mainot ledus tekstūru. Š̄is publikācijas mērkịis ir apskatīt kā ledus topogrāfija ietekmē objektu spēju sākt slīdēt uz ledus virsmas, kā arī to, kā ledus virskārta ietekmē parauga slīdēšanas ātrumu gan laboratorijas, gan lauka eksperimentos. Tika sagatavots trīs dažādu tekstūru ledus - gluds, skrāpēts un ar uzsmidzinātām pilītēm, lai imitētu trīs dabā bieži sastopamus ledus tekstūras variantus. Laboratorijas apstākḷos ledum veikti miera stāvokḷa berzes koeficienta un slīdēšanas ātruma mērījumi, bet lauka eksperimentos skeletona starta treniņa estakādē pārbaudīta ledus tekstūras ietekme slīdēšanas ātrumu. Laboratorijas apstākḷos skrāpētā ledus tekstūra uzrādīja sliktāko slīdēšanas ātrumu, kam seko gludais ledus, bet ar pilītēm apsmidzinātais ledus uzrāda labākos slīdēšanas ātrumus. Tika veikti vienkāršoti ledus tekstūras kontakta laukuma mērījumi, lai redzētu atbalsta laukuma ietekmi slīdēšanas uz procesa gaitu. Laboratorijas eksperimentos iegūtie dati tiek pārbaudīti lauka eksperimentos, izmantojot lielāka mēroga virsmas un piespiešanas spēkus. Iegūtie dati var būt noderīgi drošākas kustības pa ledu veicināšanai civilajiem iedzīvotājiem, kā arī ar ziemas sporta veidu pārstāvjiem.

04.09.2018. 